\title{
Research of Online Reviews Deviation for Sales in B2C Platform
}

\author{
Wenjun Liu ${ }^{1}$, Lin Ding ${ }^{2}$ and Cuibo Wang ${ }^{1}$ \\ ${ }^{1}$ School of Management, South-central University for Nationalities \\ ${ }^{2}$ School of Accounting and Finance, Zhongnan University of Economics and Law \\ meem2004@126.com
}

\begin{abstract}
This research focuses on online reviews deviation in $\mathrm{B} 2 \mathrm{C}$ platform, and tries to analyze the phenomenon that shops which have large sales volume are lowly recommended compared with the average in Tmall. After verifying the validity of online reviews, we find out that the consumers' sensibility for negative commentsobecome weaker. And the sellers' sincerity that reflected by their replies to negative comments have)little influence on sales. Only the number of total comments and positive comments can obviously influence on sales. Shops, in B2C platform, just concern about laking part in sales promotion to create hot products, instead of devoung to the quality of service. B2C platform whose primary business is selling entrance of users flow, prefers to protect large sellers, and the unreasonable rules in online reviews is the main reason for partial failure in the influence of reviews to sales.

Keywords: Online Reviews, Enotional Incknation; Deviation; B2C Platform; Sales Volume

\section{Introduction}

Online review is a kind of method for spreading the online word-of-mouth (Sen \& Lerman, 2007), and it is an important information sources during online shopping (Park \& Lee, 2009). Besices, it is also asignificant reference factors to forecast the sales volume (Gong, Liu \& Zhao, 2013RBeport of Chinese online shopping market 2013 pointed out that when the consumers purchasing the unfamiliar products online, "other customers' reviews" can influence their decision obviously. More than $77 \%$ consumers concerned about "customer_comments" during online shopping. Even buying the familiar products, more than $25.0 \%$ oustomers admitted customers' reviews can influence their decision.

Nevertheless, the consumers will discover intuitively that in the Tmall which has $57.3 \%$ market shares in China B2C online market, the shops that have big sales volume are lowly recommended compared with the average, and their comprehensive scores in the homepage is lower. Compared with good sales shops in Taobao, there are more negative comments in Tmall. Besides, the sellers' sincerity that reflected by their replies to negative comments in Tmall are poorer than in Taobao. Is there online reviews deviation in $\mathrm{B} 2 \mathrm{C}$ platform, under some specific business rules?
\end{abstract}

\section{Literature Review and Research Hypothesis}

This research is on the basis of the common procedure which ordinary consumers use to go online shopping, and the interview of 30 online purchasers to find out that: When consumers are going to buy one product, usually they compared many different companies who sale the same type with each other, first to rank them according the sales volume and then the price. If the prices are pretty much the same, they are about to consider the comments next. This research divides the comment index into objective variable and subjective variable based on the results of previous studies and the shopping 
procedures (Zhu \& Zhang, 2010). Besides, it also considers the factors that have no relationship to the comments but influence the increase of sales volume, and these factors are controlled or avoided during the data collection.

\subsection{Objective Variables}

These dates are located in the conspicuous place of the online stores so they are easy to be noticed and compared in the shops of Tmall, and they are include comments amount, comprehensive scores of online stores, and so on.

\subsubsection{Comments Amount}

There is a relationship between comment amounts and sales volume (Cui, Lui \& Guo, 2012), and to some extent, the sales volume can reflect the popularity of the products the larger the comments amount is, the safer the consumers perceived, and further more to increase the sales volume. In a word, the comments amount reflected how well the products being received by consumers.

Because a lot of shops in Tmall selling same products, consumers always consider the historical sales volumes to judge the comprehensiye strength of the stores, and in the other aspect, the sales volume is silent comment conducted by other consumers (Mudambi \& Schuff, 2010). Usually, consumers filter the information according to the sales volume rank.

H1a: The number of accumulative comments has significant positive influence on sales increment.

H1b: Initial sales volume has significant positixe infuence on sales increment.

\subsubsection{Comprehensive Scores of Online Stores}

The comprehensive scores of onlinestores contain three parts. They are Description conform to reliability, Service attitude and Dispatch timeliness. Generally, the high score means the high quality of the services.

H2a: The score of description conform to reliability has significant positive influence on sales.

H2b: The score of the Service attitude has significant positive influence on sales.

H2c: The score of the Dispatch timeliness has significant positive influence on sales.

\subsection{Subjective Variables}

Chevalie and Mayzlin(2006) found that there was a positive correlation between comment quality on line and sales volume. Customers pay more attention to the content of comment not only simple statistical data (Yin, Bond \& Zhang, 2014). Comment quality must be reflected by the parameters of subjective variable (Zou, Yu \& Hao, 2011). The research, in the base of other scholars' achievements and the current comment condition in Tmall, tried out subjective variable which is mainly about emotional inclination of comment (positive or negative attitude) and reply for negative comment.

\subsubsection{Emotional Inclination}

Negative and positive emotional inclination of on-line comment has a significant effect on the availability of comment (Kim \& Gupta, 2012; Ludwig et al., 2013). Commonly, positive comment can bring about affirmative emotion to the other customers so it will promote purchasing (Cheung, Sia \& Kuan, 2012; Utz, Kerkhof \& van den Bos, 2012). On the contrary, negative comments will hinder purchasing because they will deliver perception of risk to customers (Ho-Dac, Carson \& Moore, 2013).

The longer the reviews are, the more significant of the comment effectiveness 
(Mudambi \& Schuff, 2010). Long comment has a detail description and kinds of content about goods except for the meaningless ads and repeated comment (Zhou, Liu \& Tang, 2013). Shan and $\mathrm{Lu}(2010)$ found that the comment quality and quantity has a significant effect on effectiveness of comment, no matter it is positive or not.

Park and Lee (2009) divided online comment types into simple and attributive comment according its content. The latter is richer in content than the former which just contains bad or good. So they can be accepted easily by customers.

The research puts forward that emotional inclination depends on the quality of comment richness in content.

H3a: The perception of positive comments has significant positive influence on sales.

$\mathrm{H} 3 \mathrm{~b}$ : The perception of negative comments has significant negative influence on sales.

\subsubsection{Reply for Negative Comment}

Customers will pay more attention to the negative comment while ooking through comments (Cheng \& Loi, 2014). Most scholars found that negative comments can easily draw customers' eyes (Ullrich \& Brunner, 2015). It can give customers more reference value than positive comment while they make a decision duing on-line shopping (Ahluwalia, Burnkrant \& Unnava, 2000). They rould rather Seek negative comment for help. The frequency of comment reply has an important effect on the online comment effectiveness (Lin, Lee \& Horng, 2011). And the Reply for negative comment is very important to decrease perception of risk. Sincere attitude of reply for negative comment will deeply appeal customers (Park \& Allen, 2013 The research founds that sincere attitude of reply for negative comment is based on the rate and content.

H4: The sellers' sincerity that reflected by their replies to negative comments has positive influence on sales.

Presently, there are litter replies to positive comments. And most of replies for positive comment are advertisementwith no vares

\subsubsection{Other Factors}

Excepting for the cheap and captive-product, valuable goods generally have a slower sales increment than cheap commodities at the same period. Because this research involves many kinds of goods, the effect need to be controlled that caused by value of goods.

Moreover, the price is easy to be compared on line. Customers become very sensitive to price. We should avoid the effect caused by price difference for the same goods, when we gather the data.

\section{Research Design}

\subsection{Variable Definition}

According to the above hypothesis, the quantitative index can be set up. Objective variables can be collected directly from web pages, mainly contains the number of cumulative comment (X1), sales volume(X2), as well as description conform to reliability (X3), service attitude(X4), Dispatch timeliness (X5).

Subjective variables cannot be collected directly from web pages. It must be calculated and transformed by many rules.

Comment on emotional inclination refers to the commodity includes positive emotions (X6) and negative emotion (X7), emotional inclination is determined by the number of comments and their contents' richness. Otherwise, the Former-Effect should be considered, and the former the comments are, the easier to be concerned. 
As for positive emotions, this research records the first 5 pages of comments, comments with the picture, as well as appends comment, and we give different weight to the contents. In all kinds of comments, the weight of home page is 5; the weight of second page is 4 and so on. In addition, Attribute Reviews with long content, are given twice extra weight, but the same comments only calculate once. The final summary is positive emotional score.

As for negative emotions, because of the protection of Tmall for the shops, in some conditions, the negative comments cannot be read directly, so consumers need to go through the first few pages comment to obtain basic perception. Some goods provide keywords of negative comment. In the case, consumer can read negative comments directly. Whether there are negative keywords or not, negative comments in append comments, comments with the picture, should be considered. Therefore, the number of negative comments from the first 5 pages of comments, append comment are weighted according to the number of comment pages, for Attribute Reviews with long content, are given twice extra weight, but the same comments only calculate once.

The sellers' attitude of negative comment replies(X8), Which is determined by the recovery ratios and reply content. We calculated the recovery ratios of negative comment from the first five pages comments, append comment, comment with pictures. Then five researchers, in our team, with experiences in online shopping, read the reply for negative comments by themselves and evaluate the fitness. When sellers explain the problem with mild tone, also have patience and careful answers, 5 is recorded, if their reply is nothing to do with problems, 3 points is recorded, however, they choose to yell to answers, 1 point is recorded. Also they need to judge bythemselves of $/$ middle fractions. Then we compare the scores that been put up by five tesearcher, when the difference is bigger, we need to review scores, and repeat the procedure again. If the difference is little, we choose the averages and round according to the methods of the rounding off. Finally we multiply the recovery ratios as the final seores of sellers reply for negative comments.

The dependent variable chooses sales inerement $(\mathrm{Y})$.

So, the model of online reviews deviation for sales is shown as follow.

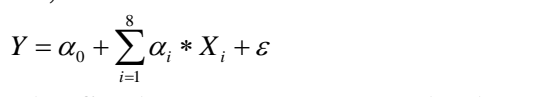

The final measurement methods of the quantitative indexes are shown as Table 1.

Table 1. Variable Definition and Measurement Methods

\begin{tabular}{|c|l|l|}
\hline Assuming factor & \multicolumn{1}{|c|}{ Variable } & \multicolumn{1}{c|}{ Measurement Method } \\
\hline $\begin{array}{c}\text { Comment Number } \\
\mathrm{H} 1 \text { (objective) }\end{array}$ & namber of accumulative Comment $\mathrm{X}_{1}$ & Record shop data directly \\
\cline { 2 - 3 } & Sales volume $\mathrm{X}_{2}$ & Record store data directly \\
\hline $\begin{array}{c}\text { Shop SCore } \mathrm{H} 2 \\
\text { (objective) }\end{array}$ & description conform to reliability $\mathrm{X}_{3}$ & Record store data directly \\
\cline { 2 - 3 } & service attitude $\mathrm{X}_{4}$ & Record store data directly \\
\cline { 2 - 3 } $\begin{array}{c}\text { Emotional } \\
\text { Inclination } \mathrm{H} 4 \\
\text { (subjective) }\end{array}$ & Dispatch timeliness $\mathrm{X}_{5}$ & Record store data directly \\
\cline { 2 - 3 } & Perception of positive comment $\mathrm{X}_{6}$ & $\begin{array}{l}\text { According to the quantity, content, } \\
\text { location, calculated according weight }\end{array}$ \\
\hline $\begin{array}{c}\text { Negative comment } \\
\text { Reply H6 } \\
\text { (subjective) }\end{array}$ & $\begin{array}{l}\text { attitude of Negative comment Reply } \\
\mathrm{X}_{8}\end{array}$ & $\begin{array}{l}\text { According to the quantity, content, } \\
\text { location, calculated according weight } \\
\text { rates, content score, multiply the } \\
\text { scoring }\end{array}$ \\
\hline
\end{tabular}

\subsection{Data Collection}

In this paper, from the collection of corresponding users' comments in Tmall, we needed to determine the types of goods, the shops, the goods and the time 
interval of data collection.

On the basis of the study of Nelson (Nelson, 1970, 1974), the types of products contained the Search type and Experience type. Although most of scholars believed that it was necessary to distinguish goods of search type and experience type (Huang, Lurie \& Mitra, 2009), Nelson believed that the limit of goods of search type and experience type had increasingly blurred because consumers could browse online comment freely. Susan M. Mudambi, Mudambi gathered six types of products (MP3 player, music CDS, video games, digital cameras, laser printer) at amazons to analyze the online comment, the choosing standard was only that the users' comments on these goods were richer. The standard of choosing goods on our study was that there were more shops, more products; more comments, larger sales and their price were moderate. The final selected categories were clothing (including clothes, pants and skirt), shoes, mobile phone, headphone, USB sticks.

After confirming the kinds of goods, we needed to choose different stores as the research objects according to the categories of goods. Threeddays in advance, this research team randomly browsed and chose 2000 items in the category of provisions, recording their URL and giving them the order number. At the beginning of data collection, we used SPSS to choose 600 items randomly, according to the judgment condition "sales larger, and there is not any shop whose price of goods are significantly lover" "comments are more than 5 pages", and we eventually chose 500 shops and the corresponding goods in Tmall as formal research objects. This method avoids the personal subjective preference affecting the samples' representativeness, also-aviding the impact of the price difference between different shops of the same goods. But this method can't represent the total, especially the shops in bad sales situation, because the samples selected are all in good sales.

In addition, we must avoided holiday sales promotion when collecting data. Sales increase yould be too little if the interval was too short and comment data would change too mach if the interval was too long. At the same time, the merchants often took part in sales promotion activity, the longer the interval, the more merchants taking part in the activity, and the more sample contradicted with the choosing rules. In this research, we determined whether the merchants took part in the adtivity by the data "the history of price changes of the goods". In order to determine how long the interval was suitable, the research analyzed on 30 kinds of goods and their corresponding shops in advance, finding one week (7 days) as interval was more appropriate.

Finally, we collected 500 copies of different goods and the corresponding shops' information and recorded data again, 7 days later. We found that there were 103 items taking part in the promotion activity; there were 91 items that other shops took part in price-off promotions activity significantly; there were 67 items deleted by merchants and the sales growth of another 6 items was negative because of return and exchange and other factors. Finally we got 233 valid data. Final goods distribution in different categories is shown as Table 2. 
Table 2. Commodity Distribution Statistics

\begin{tabular}{|l|c|c|}
\hline Category & Number of goods & The proportion \\
\hline Shoes & 45 & 0.19 \\
\hline Coat & 34 & 0.15 \\
\hline Pants/skirt & 39 & 0.17 \\
\hline Mobile phone & 49 & 0.21 \\
\hline Headphone & 45 & 0.19 \\
\hline USB sticks & 21 & 0.09 \\
\hline The total & 233 & 1 \\
\hline
\end{tabular}

\subsection{Results and Analyses}

The study using the correlation analysis to examine the multicollinearity, and use the factor analysis to remove the effect of multicollinearity, then, using linear regression to test the relationship between independent variable and dependent variable after extracting. Before the formal analysis, in order to eliminate the influence of the unit of measure, we standardized 8 independent yariables and one dependent.

\subsubsection{Correlation Analysis}

Inspection index is the correlation coefficient between each independent variable in correlation analysis. Andif the correation coefficient was greater than or close to 0.8 , the multicollinearity between the independent variables existed. We analyzed the correlation matrix of 8 independent variables. The results are shown as Table 3.

Table 3. Correlation Analysis

\begin{tabular}{|c|c|c|c|c|c|c|c|c|}
\hline & $\begin{array}{l}\text { Month } \\
\text { Sales } \\
\text { Volum }\end{array}$ & $\begin{array}{l}\text { Number of } \\
\text { ccumulative } \\
\text { Comment }\end{array}$ & $\begin{array}{l}\text { Negative } \\
\text { Comment }\end{array}$ & $\begin{array}{l}\text { Reply for } \\
\text { Negative } \\
\text { Comment }\end{array}$ & $\begin{array}{l}\text { Positive } \\
\text { Comment }\end{array}$ & $\begin{array}{l}\text { Description } \\
\text { Conform to } \\
\text { Reliability }\end{array}$ & $\begin{array}{l}\text { Service } \\
\text { Attitude }\end{array}$ & \begin{tabular}{|l} 
Dispatch \\
Timeliness
\end{tabular} \\
\hline $\begin{array}{l}\text { Monthly Sales } \\
\text { Volume }\end{array}$ & & Q & & & & & & \\
\hline $\begin{array}{c}\text { Number of } \\
\text { Accumulative } \\
\text { Comment }\end{array}$ & & 1 & & & & & & \\
\hline $\begin{array}{l}\text { Negative } \\
\text { Comment }\end{array}$ & -.024 & -.037 & 1 & & & & & \\
\hline $\begin{array}{l}\text { Reply for } \\
\text { Negative } \\
\text { Comment }\end{array}$ & .396 & .391 & .290 & 1 & & & & \\
\hline $\begin{array}{l}\text { Posikive } \\
\text { Comment }\end{array}$ & .251 & .380 & .246 & .136 & 1 & & & \\
\hline $\begin{array}{l}\text { Description } \\
\text { Conform to } \\
\text { Reliability }\end{array}$ & .022 & -.008 & .010 & .083 & -.030 & 1 & & \\
\hline $\begin{array}{l}\text { Service } \\
\text { Attitude }\end{array}$ & .015 & -.023 & -.060 & .055 & -.068 & .792 & & \\
\hline $\begin{array}{c}\text { Dispatch } \\
\text { Timeliness }\end{array}$ & .044 & -.008 & -.062 & .066 & -.055 & .768 & .793 & 1 \\
\hline
\end{tabular}

It can be seen from Table 3, there are 5 correlation coefficients close to or greater than 0.8 .And according to the contact between them, and they can be divided into two classes:

(1) Monthly Sales Volume and Accumulative Comment: correlation 
coefficient $(0.893)$;

(2) Description Conform to Reliability and Service Attitude: correlation coefficient (0.792);

(3) Description Conform to Reliability and Dispatch Timeliness: correlation coefficient $(0.768)$;

(4) Dispatch Timeliness and Service Attitude: correlation coefficient (0.793).

\subsubsection{Factor Analysis}

Removing the effect of multicollinearity, we extracting factors from 5 variables and calculate factor score that participate in the linear regression equation. In this study, we use the SPSS 21 to calculate and the result shows that the KMO value was of 0.654 . The Bart Litas sphere test value was significant in 0.01 lepels. After the Kaiser standardized orthogonal rotation, factor loading matrix was as shown in Table 4, of which 2 factors were extracted, explained $89.256 \%$ of the total variance. Each factor explaining the variances accumulator was listed in the last line of the table. The factor's names are shown in the ehart of the second line.

Table 4. After Standardization of Orthogonal Rotation Factor Loading Matrix

\begin{tabular}{|l|r|r|}
\hline & & \multicolumn{2}{c|}{ Principal Components } \\
\hline Service attitude & Shop score & Total Quantity \\
\hline Description reliability & $\mathbf{9 3 2}$ & -.009 \\
\hline Dispatch timeliness & $\mathbf{. 9 2 2}$ & .016 \\
\hline Number of accumulative Comment & $\mathbf{. 9 2 2}$ & .003 \\
\hline Monthly sales volume & -.019 & $\mathbf{. 9 7 3}$ \\
\hline
\end{tabular}

The accumulative comment and sales volume were extracted as a factor named as the total quantity $\left(\mathrm{z}_{1}\right)$.

The description, reliability, seryice attitude and delivery speed were extracted as a factor named as the Shop score $\left(\mathrm{Z}_{2}\right)$.

So, the model of online reviews deviation for sales is changed, and the new formula is shown as follow.

\subsubsection{Regression Analysis}

$$
Y=\beta_{0}+\beta_{1} * \mathrm{Z}_{1}+\beta_{2} * \mathrm{Z}_{2}+\beta_{3} * \mathrm{X}_{6}+\beta_{4} * \mathrm{X}_{7}+\beta_{5} * \mathrm{X}_{8}+\varepsilon
$$

The significance of regression equation inspection is to test whether the linear reationship of variables and all variables is significant. This article uses the multiple regression method to test the effects of online comments on sales volume in which the dependent variable is the value of commodity Sales Increment (Y), and explanatory variables contained 2 factor scores and 3 independent variables: Total Quantity $\left(\mathrm{Z}_{1}\right)$, Shop score $\left(\mathrm{Z}_{2}\right)$, Positive Emotional $\left(\mathrm{X}_{6}\right)$, Negative Emotion $\left(\mathrm{X}_{7}\right)$, Reply for Negative comment $\left(\mathrm{X}_{8}\right)$.

Inspection and coefficient of model variables are shown in Table 5. 
Table 5. Model Test Results

\begin{tabular}{|c|c|c|c|c|c|c|c|c|c|}
\hline & (1) & (2) & (3) & (4) & (5) & (6) & (7) & (8) & (9) \\
\hline $\begin{array}{c}\text { Total } \\
\text { quantity }\end{array}$ & $\begin{array}{c}0.521 * * * \\
(15.912)\end{array}$ & & & & & $\begin{array}{c}0.677 * * * \\
(14.327)\end{array}$ & $\begin{array}{l}6.90 * * * \\
(13.938)\end{array}$ & $\begin{array}{c}0.644 * * * \\
(12.634)\end{array}$ & $\begin{array}{c}0.616^{* * * *} \\
(11.861)\end{array}$ \\
\hline $\begin{array}{l}\text { Positive } \\
\text { comment }\end{array}$ & & $\begin{array}{c}0.363 * * * \\
(5.924)\end{array}$ & & & & $\begin{array}{c}0.143 * * \\
(3.034)\end{array}$ & & $\begin{array}{c}0.143 * * \\
(3.038)\end{array}$ & $\begin{array}{l}1.641^{*} \\
(3.390) \\
\end{array}$ \\
\hline $\begin{array}{l}\text { Negative } \\
\text { comment }\end{array}$ & & & $\begin{array}{l}-0.036 \\
(-.547) \\
\end{array}$ & & & & & & $\begin{array}{l}-0.097 * \\
(-1.999) \\
\end{array}$ \\
\hline $\begin{array}{l}\text { Reply for } \\
\text { Negative } \\
\text { comment }\end{array}$ & & & & $\begin{array}{c}0.361 * * * \\
(5.889)\end{array}$ & & & $\begin{array}{c}0.083 \\
(1.668)\end{array}$ & $\begin{array}{c}0.082 \\
(1.683)\end{array}$ & $\begin{array}{l}0.125^{*} \\
(2.440)\end{array}$ \\
\hline Shop Score & & & & & $\begin{array}{c}-0.093 \\
(-1.425)\end{array}$ & & & & $\begin{array}{c}-0.097 * \\
(-2.19)\end{array}$ \\
\hline $\mathrm{N}$ & 233 & 233 & 233 & 233 & 233 & 233 & 233 & 233 & 233 \\
\hline Adj-R ${ }^{2}$ & 0.521 & 0.128 & 1 & 0.127 & 1 & 0.537 & 0.525 & 0.541 & 0.553 \\
\hline
\end{tabular}

(Note: *is significant in level of $0.05 ; * *$ is significant in level of $0(01 ; * * *$ *is significant in level of 0.001.)

The models are shown as follow.

$$
\begin{aligned}
& Y=\beta_{0}+\beta_{1} * \mathrm{Z}_{1}+\varepsilon \\
& Y=\beta_{0}+\beta_{1} * \mathrm{X}_{6}+\varepsilon \\
& Y=\beta_{0}+\beta_{1} * \mathrm{X}_{7}+\varepsilon \\
& Y=\beta_{0}+\beta_{1} * \mathrm{X}_{8}+\varepsilon \\
& Y=\beta_{0}+\beta_{1} * \mathrm{Z}_{2}+\varepsilon \\
& Y=\beta_{0}+\beta_{1} * \mathrm{Z}_{1}+\beta_{2} * \mathrm{X}_{6}+\varepsilon \\
& Y=\beta_{0}+\beta_{1} * \mathrm{Z}_{1}+\beta_{2} * \mathrm{X}_{8}+\varepsilon \\
& Y=\beta_{0}+\beta_{1} * \mathrm{Z}_{1}+\beta_{2} * \mathrm{X}_{6}+\beta_{3} * \mathrm{X}_{8}+\varepsilon
\end{aligned}
$$

Model (1) - (5) is a judge for whether each independent variable had a significant influence alone on the dependent variable "sales increment" or not. The result shows that the total quantity had a significant influence alone on sales increment so as favorable comment and negative comment reply. While the negative comment and shop score hadn't a significant influence on the sales increment;

Model (6) shows that the union of total quantity and favorable comment had a significant influence on sales increment.

Model (7) shows that while the total quantity and negative comment reply jointly affecting the sales increment, the influence of total quantity was significant ,the influence of negative comment reply wasn't significant ;

Model (8) shows that while the total quantity, favorable comment and negative comment reply jointly affecting the sales increment, the influence of both total quantity and favorable comment was significant, the influence of negative comment reply wasn't significant;

Model (9) puts all the variables into the model, the results shows that all variables were significant, in which the shop score had a significant negative influence on sales increment. It had violated the research hypothesis 2 , but was consistent with the actual observation. 
From model (1) - (9), we can find that the total quantity and favorable comment both had a significant and steady influence on sales increment, the influence of the total quantity explained the sales increment variation, the vast majority of the variance of the proof for the sales increment contribution was most obvious. For the most part, total quality explained the sales increment of variance and proved its the most obvious contribution to sales increment.

\section{Conclusions}

Based on the preceding analysis, we can get a conclusion that the hypothesis $\mathrm{H} 1$ and $\mathrm{H} 3 \mathrm{a}$ are accepted, and the $\mathrm{H} 2$ is refused, and $\mathrm{H} 3 \mathrm{~b}$ and $\mathrm{H} 4$ should be further verified. The results are shown as Table 6.

Table 6. The Result of Empirical Analysis

\begin{tabular}{|c|c|c|c|}
\hline Hypothesis & $\begin{array}{l}\text { Hypothesis } \\
\text { Segment }\end{array}$ & Hypothesis Content & Results \\
\hline \multirow{2}{*}{ H1 } & H1a & $\begin{array}{l}\text { The number of accumulative comment has } \\
\text { significant positive influence on sales increment }\end{array}$ & Accept \\
\hline & $\mathrm{H} 1 \mathrm{~b}$ & $\begin{array}{l}\text { Initial sales volume has significant positive } \\
\text { influence on sales ncyement. }\end{array}$ & Accept \\
\hline \multirow{3}{*}{$\mathrm{H} 2$} & $\mathrm{H} 2 \mathrm{a}$ & $\begin{array}{l}\text { The score of the description online stores has } \\
\text { significant positive influepce on sales }\end{array}$ & Refuse \\
\hline & $\mathrm{H} 2 \mathrm{~b}$ & $\begin{array}{l}\text { The score of the "service" online stores has } \\
\text { signfifieant positive influence on sales }\end{array}$ & Refuse \\
\hline & $\mathrm{H} 2 \mathrm{c}$ & $\begin{array}{l}\text { The score of the "Yogistics" online stores has } \\
\text { significant positive influence on sales }\end{array}$ & Refuse \\
\hline \multirow{2}{*}{$\mathrm{H} 3$} & $\mathrm{H} 3 \mathrm{a}$ & $\begin{array}{l}\text { The perception of favorable comments has } \\
\text { significant positive influence on sales. }\end{array}$ & Accept \\
\hline & & $\begin{array}{l}\text { The perception of negative comments has significant } \\
\text { negative influence on sales. }\end{array}$ & To be verified \\
\hline $\mathrm{H} 4$ & & $\begin{array}{l}\text { The sincere attitude that merchants replay to } \\
\text { negative comments has positive influence on sales }\end{array}$ & To be verified \\
\hline
\end{tabular}

The research results show that, among the Tmall is the same as the Taobao, the total sales volume is the most important indicator, but consumers have lower sensitivity to negative comments. There are two main reasons. First, because the merchants have the brand certification, more consumers trust their commodity quality Tmall. Second, the Tmall don't distinguish the positive comments and negative comments specially in order to protect the merchants. A consumer is not easy) to find the negative comments directly. Although, some products' problems can be found through the product description keywords, lots of shops don't provide problems keywords.

Because it is very difficult for consumers to find all of the negative comments, beside the sales volume of the Tmall are very large, a few negative comments are submerged in a lot of positive comments which most of them are set by the system. So the sellers don't have the interests to reply negative comments.

Moreover, the comprehensive scores of online stores have no effect on the sales, from the point of coefficient, is even on the opposite direction, the lower the score of online shop is, the larger the sale. This deviation shows that merchants who have the larger sales don't pay more attention to the quality of service, even because of the lack of manpower, the merchant reduced the quality of service 
deliberately in order to save the cost of the human resource, such as fewer after-sales service persons to replay customers' questions. This deviation confirms to the actual situation. At present, the merchants only care about taking part in sales promotion to create hot products, instead of devoting to the quality of service. B2C platform whose primary business is selling entrance of users flow, just like Tmall, prefer to protect large seller, and the unreasonable rules in online reviews is the main reason for partial failure in the influence of reviews to sales.

This research confirm the online reviews deviation in Tmall, and find out what factors still valid in online reviews to sales increment. But there are also some insufficiencies, for example, samples all belongs to shops in good sale, so it does not represent all, especially, the shops in bad sales. Although we try best to avoid the subjective influence that conducted by researchers, when analyzing the comments, we can't avoid personal subjective judgment absolutely. Sometimes, it is hard to sort some comments to positive or negative reviews. There may be exist comprehending deviation, especially for the comments that include both praise and criticism to the products.

\section{Acknowledgements}

This paper is supported by "the Nationals Social Science Foundation of China" (Grant Number: 14CTQ017).

\section{References}

[1] S. Sen and D. Lerman, Why are you telling me this? An examination into negative consumer reviews on the web", Journal of interactiye marketing, vot. 4, no. 21, (2007).

[2] D. H. Park and J. Lee, "eWOM overload and its effect on consumer behavioral intention depending on consumer involvemênt", Electronic Commeree Research and Applications, vol. 4, no. 7, (2009).

[3] S. Y. Gong, X. Lit and P. Zhao, "How Do Online Consumer Reviews Influence Product Sales?", An Empirical Study Based on Online Book Reviews, China Soft Science, vol. 6, (2013).

[4] F. Zhu and X. Zhang, "Impact of online consumer reviews on sales: The moderating role of product and consumer characteristics", Journal of marketing, vol.2, no. 74, (2010).

[5] G. Cui, H. K. Lui and X Guo, "The effect of online consumer reviews on new product sales", International Journal of Electronic Commerce, vol. 1, no. 17, (2012).

[6] S. M. Mudambi and Dy Schuff, "What makes a helpful review?", A study of customer reviews on Amazon. com. MIS quarterly, vol. 1, no. 34, (2010).

[7] J. A. Chevalier and D. Mayzlin, "The effect of word of mouth on sales: Online book reviews", Journal of marketing research, vol. 3, no. 43, (2006).

[8]D. Yin, S. Bond and H. Zhang, "Anxious or angry? Effects of discrete emotions on the perceived helpfulness of online reviews", MIS quarterly, vol. 2, no. 38, (2014).

[9] P. Zou, B. Yu and Y. Hao, "Does the valence of online consumer reviews matter for consumer decision

making? The moderating role of consumer expertise", Journal of computers, vol. 3, no. 6, (2011).

[10] J. Kim and P. Gupta, "Emotional expressions in online user reviews: How they influence consumers' product evaluations", Journal of Business Research, vol. 7, no. 65, (2012).

[11] S. Ludwig, K. De Ruyter, M. Friedman, E. C. Brüggen, M. Wetzels and G. Pfann, "The influence of affective content and linguistic style matches in online reviews on conversion rates", Journal of Marketing, vol. 1, no. 77, (2013).

[12] C. M. Y. Cheung, C. L. Sia and K. K. Kuan, "Is this review believable? A study of factors affecting the credibility of online consumer reviews from an ELM perspective", Journal of the Association for Information Systems, vol. 8, no. 13, (2012).

[13] S. Utz, P. Kerkhof and J. van den Bos, "Consumers rule: How consumer reviews influence perceived trustworthiness of online stores", Electronic Commerce Research and Applications, vol. 1, no. 11, (2012).

[14] N. N. Ho-Dac, S. J. Carson and W. L. Moore, "The effects of positive and negative online customer reviews: Do brand strength and category maturity matter?", Journal of Marketing, vol. 6, no. 77, (2013).

[15] M. Zhou, M. Liu and D. Tang, "Do the characteristics of online consumer reviews bias buyers' purchase intention and product perception? A perspective of review quantity, review quality and negative review sequence", International Journal of Services Technology and Management, vol. 4, no. 19, (2013). 
[16] C. Shan and Y. B. Lu, "A Study on the Effects of Positive and Negative Online Reviews on Consumers' Initial Trust in C2C Vendors", Library and Information Service, vol. 12, (2010).

[17] V. T. Cheng and M. K. Loi, "Handling negative online customer reviews: the effects of elaboration likelihood model and distributive justice", Journal of Travel \& Tourism Marketing, vol. 1, no. 31, (2014).

[18] S. Ullrich and C. B. Brunner, "Negative online consumer reviews: Effects of different responses", Journal of Product \& Brand Management, vol. 1, no. 24, (2015).

[19] R. Ahluwalia, R. E. Burnkrant and H. R. Unnava, "Consumer response to negative publicity: The moderating role of commitment", Journal of marketing research, vol. 2, no. 37, (2000).

[20] C. L. Lin, S. H. Lee and D. J. Horng, "The effects of online reviews on purchasing intention: The moderating role of need for cognition", Social Behavior and Personality: an international journal, vol. 1, no. 39, (2011).

[21] S. Y. Park and J. P. Allen, "Responding to online reviews problem solving and engagement in hotels", Cornell Hospitality Quarterly, vol. 1, no. 54, (2013).

[22] P. Nelson, "Information and consumer behavior", Journal of Political Economy, vol. 2, no. 78, (1970).

[23] P. Nelson, "Advertising as information. Journal of Political Economy", vol. 4, no. 82, (1974)

[24] P. Huang, N. H. Lurie and S. Mitra, "Searching for experience on the web: an empirical expmination of consumer behavior for search and experience goods", Journal of Marketing, vol. 2, no. 73, (2009).

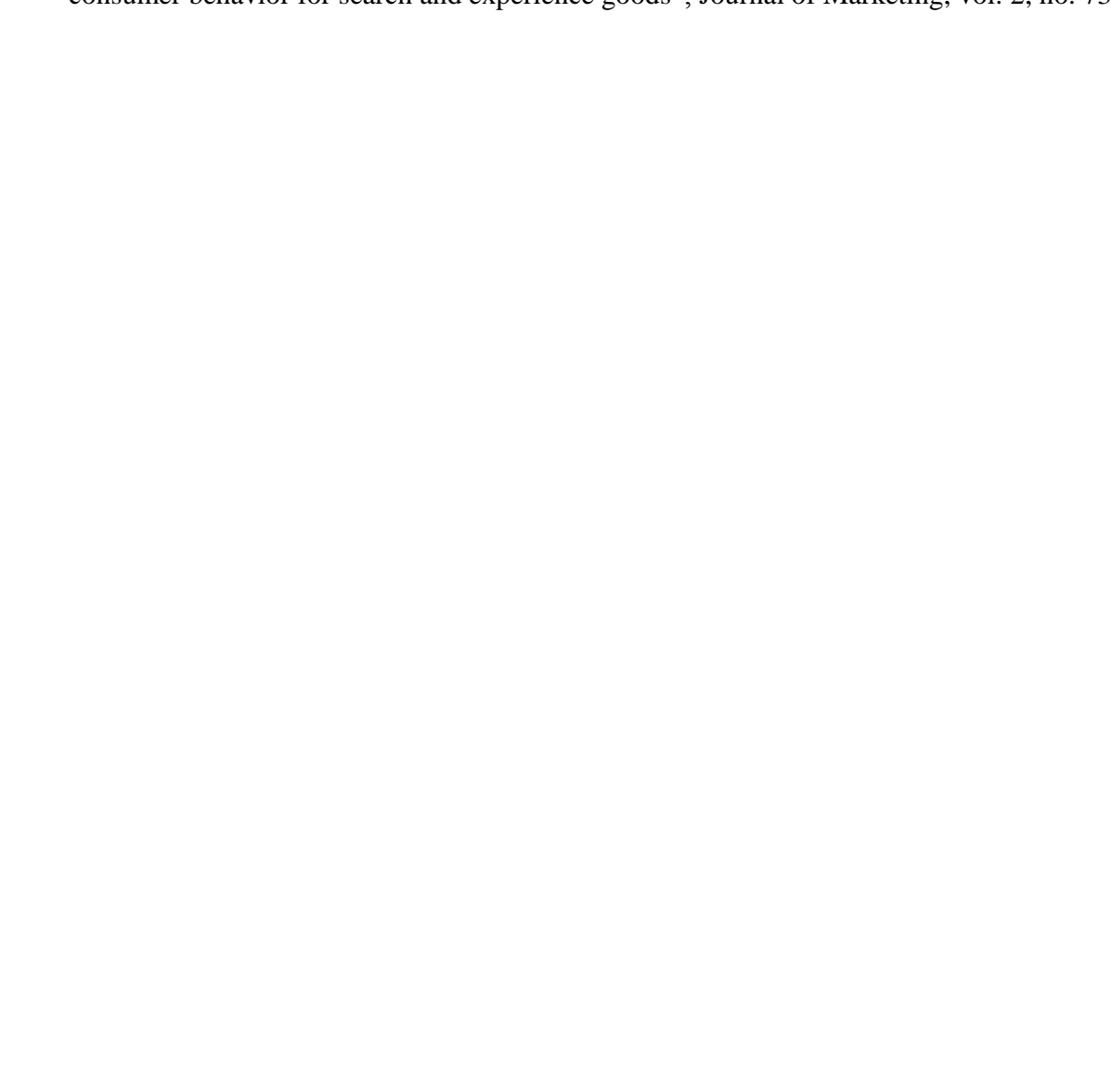


International Journal of Hybrid Information Technology

Vol. 9, No.8 (2016)

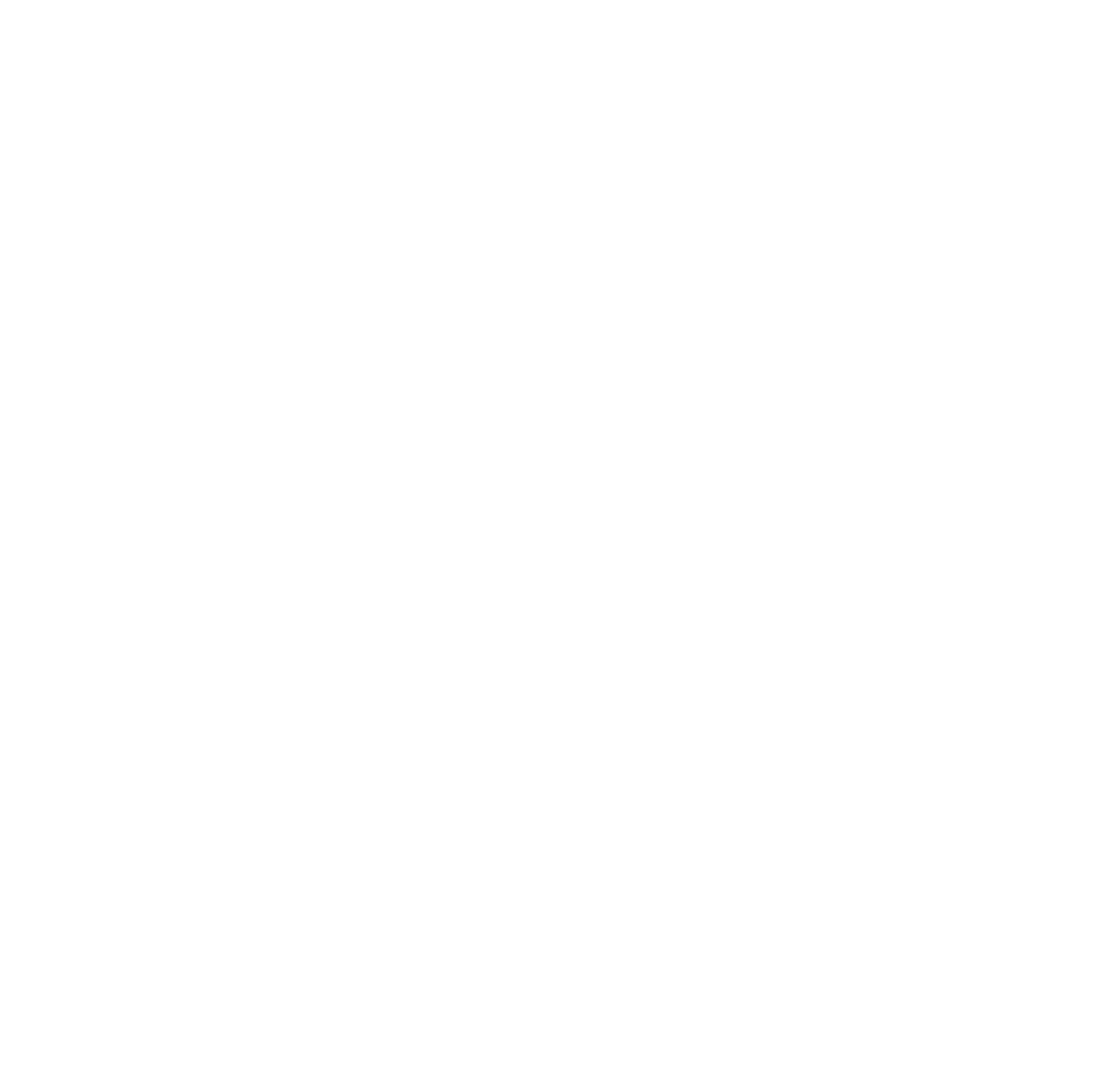

